\title{
Political Participations of Rural Communities
}

\author{
R. M. Ramdhan \\ Sociology Major, Padjadjaran University \\ Bandung, Indonesia \\ rimura1924@gmail.com
}

\begin{abstract}
Political participation is one of the salient aspects in a development. This research was conducted to rural communities in Sukabumi, West Java, with the purpose of investigating how rural communities' political participations were and the affecting factors of the participations. The research employed qualitative approach with descriptive method. The result gained from the research was that rural communities' political participation in election was still low and it was because their political awareness was still lacking. In addition, other factors influencing the communities' political participations were encouragement from formal leaders or informal leaders, facilities and infrastructures in political events, political education, interest in certain political aspects.
\end{abstract}

\section{Keywords: rural communities; political participations}

\section{BACKGROUND}

Political participations in a society are a function from priorities which are given to variables and purposes and from development strategies as a whole. Political involvement is good for society in making more meaningful development and stimulating government to be more responsive, and that is good for individual because it can make individual more civilized and more responsible citizen in a society.

Political participation is divided in two aspects, they are: first, conventional political participation, which is a form of political participation that is general in modern democracy such as voting, political discussion, campaign, joining groups' importance. Second, non-conventional political participation, which is a form of unusual political participation in a normal condition, and even it can be illegal events, full of violence, and revolutionary such as petition submission, demonstration, confrontation, political harassment behavior, revolution, and any other forms [1].

This research is more specific to observe forms of political participations of rural communities in terms of voting. Voting in the national level is conducted through General Election (Pemilu) and in the local level is conducted through Local General Election (Pilkada). General election in the national level is means of electing the president, the vice president, and the house of representative members. While for Local General Election, it is means of electing governors, vice governors, mayors/regents, vice mayors/vice regents, and local members of the local house of representative.

Society's political participation is not separated from the conditions or political systems that are being undergone. Political systems in Indonesia, until now, have been changed several times, starting from the New Order to the Reformation Era. It is realized that reformation is always thought as a more democratic era. Political participation level in Indonesia during General Election in 1955 was about 91.4\%, 1971 General Election was 96.6\%, 1977 and 1982 General Elections were 96.5\%, 1987 General Election was 96.4\%, 1992 General Election was 95.1\%, 1997 General Election was 93.6\%, 1999 General Election was 92.6\%, 2004 General Election was $84.1 \%$, and the 2009 General Election was $70.9 \%$. Meanwhile, in Nagrak Regency, Sukabumi, West Java, the level of the society's political participation in the President General Election reached 78.2\% [2].

In 2010, Sukabumi society, West Java, had administered local general election to elect the regent and the vice regent for the period of 2010-2015. Then, the West Java governor election in 2013. From the result, the observed facts from the field was gained that the level of political participations of Nagrak society, West Java, in local general election in 2010 was only $62.9 \%$. Otherwise, in governor election, it was only $68.4 \%$, meaning that more than $30 \%$ of the society in Nagrak Regency, West Java, did not participate in the process of both regent and governor election.

The lacking indicator of the low political participation of the traditional society is seen from the small initiative empowerment of the society towards phenomena and changes, and even changes that are related to their own future. If we talk about Indonesian's backward, it surely comes from the rural communities. The issue can be tolerated since most of Indonesian citizens reside in rural areas [3]. If we look closer, previous administration of the developments placed the government as if they were single agents of development, while rural communities were placed as unable groups and were underdeveloped [4].

All aspects related to policies of the development directions for rural communities need important roles of vital people in the society. Surely, it is ironical when local autonomy, in fact, requires high participation level of the society. As a result, if this condition is regarded as an obstacle to local autonomy administration and the development of rural communities, then it is the time for vital people in the society to act to improve and make changes towards political culture of traditional communities.

Political behavior can be understood as a readiness to react towards certain political objects, as a result of that object appreciation. In political life, it is seen several phenomena. The issued policies by authorized parties arouse many reactions, some may accept, some may refuse, some make soft protest, demonstration, and some even choose to be silent without reacting anything [5].

Those kinds of reactions are always shown by rural communities in facing a phenomenon. It is appreciated when "silent majority" movement as a form of their 
political participation. Although, what is worried from that silent movement is solely the people do not appreciate objects of certain conditions in their surroundings. This condition becomes bigger worry occurred in rural communities along with their traditional characteristics.

The problem is not from their traditional culture values, but the effect of their less care and less attention towards social and political life. Thus, changes or alternatives of society's social tradition will not become taboo. On the contrary, changes are needed to improve the society's life.

Departing from the background aforementioned, how are rural communities' political participations in Sukabumi, West Java?

\section{METHODS}

This research employed qualitative approach. The reasons of employing qualitative approach were: (1) Qualitative research possesses more attention to process that results or products; (2) Qualitative research is drawn towards meanings, that is how people strive to understand life, experience, and their structure of environment; (3) Qualitative researcher is the main instrument in collecting and analyzing data; (4) Qualitative research is closely related to fieldwork. It means that, researcher physically involves with people, settings, places, or institutions to observe or write down behaviors in their scientific background; (5) Qualitative research has descriptive characteristics, it means that researcher is interested in processes, meanings, and understandings that are gained from words or pictures [6].

\section{DISCUSSIONS}

Approaching general election moment, many promises are conveyed to society by all leader candidates. Realizing that sometimes realities are not in line with what is expected is a form of simple critical society. Critical society is a dream of a mature, developed, and big nation. In the middle of riots and euphoria of democracy party, the urgency of making critical society is becoming intense, and one of the ways is through political education.

A society is said to be politically literate meaning that they are the society that is able to be actively involved in government. While political education is the learning process and understanding about rights, obligations, and responsibilities of every citizen in nation and state life.

In terms of political education, it is not only about spreading the ways to elect properly and accepted, but also a political education should become wider than only explanation of normativeand systematic aspects. For instance, from all local general election events, governor election, and president election, the abundant breaches during election were not realized by the society, from bringing up children during campaign to money politics are the examples that general election has become a procedural momentum to enliven the so-called democracy. The reflection of critical society that is developing for the country should have been seen from the society responses towards political campaigns of the candidates.
The obstacles that are faced by rural communities are very complex, such as the quality of human resources that is still inadequate due to inequality of education, the low education of society's political life, unstable economic condition, the high level of working people that are not yet accepted due to limited vacancies, the condition of unrecovered social-political life, and mentally behavior of the society that is ignorant about development policies and any other aspects.

From those obstacles, if we explain more detail, first from the level of education, the low level of education in rural areas can be caused by such factors as the expensive rate of education, the lack of parents' attention to their children's education, antipathy behavior that regards education is a waste of money, assumption that education is not important than making money (working), and limited economy to afford proper education. Second, from the income level of the society that is still low. In fact, to develop human resources, widen job vacancies have been put as the foundation of rural development planning.

Then, some aspects causing the society to be reluctant to participate in politics are influenced by several things. First, political reasons, the society did not want to participate in electing future leaders because of the lack of trust to the organizers of the nation that are probably corrupt. Second, because of technical factor, that was the lack of socialization factor from the election committee. Third, apathy factor, the society did not really care of election because they were bored of broken promises by the leaders as well as the unexpected behaviors.

The role of vital people is really needed. They should massively interact or create good communication to develop society's awareness of politics. This aspect is important since there are many elements that should be involved together.

Ideally, rural communities behave in accordance with the roles of symbols in social environment. In this process, the symbolic interactionism is very dominant. This is because the process of political participation of rural society is not separated from roles of symbols. It can be seen from communication process that is built by the vital people to the society, as well as to the environment. This interaction can develop distinct image for the society and the image will support the society to participate in politics.

In relation to the concept of symbolic interactionism, it is explaned that assumptions that become the sources and bases of the study of symbolic interactionism communication occurred in the world as follows. First, symbol exchange that is interrelated. Second, self is made from communication. Third, social activity is possible through the process of others' role overtaking [7].

Those three assumptions, according to him, put the view that in every communication, one does not pay attention to individual behavior in communication, but he or she observes the individual in the middle of togetherness in their communication. Human communication personally occurs not only because of the personal actions but also because of their membership in the society.

In that condition, an individual can be understood because they interact, relate to, and transact with others. 
The actions appearing in the form of communication acts occurred not only because of independent actions but also their position and influence in the membership and the presence in the society. Human, in this perspective, takes others' roles as though they were in a drama in communicating. The aspects of symbolic interactionism are self, society, symbol relationship, meanings division, orientation, and roles taking.

Those aspects are outside this perspective, that is, every human not only has one self. Human that has one self, is only in a psychological condition from psychological perspective. In this perspective, the existing self is more than one. It shows that each person, their selves and personalities are many. Due to many influencing environments, an individual tends to choose the environment that suits them in terms of the communication acts.

An individual acts in the sense of abstract things or can be said as unobserved ideas. Inside the brain, mental learning process is closed prior to commencing real actions that are concrete in the form of seen behaviors. The meaning of mind is a process where an individual interacts with themselves and their environment using meaningful symbols [8].

The meanings are from social processes and results from interactional processes with themselves. An individual firstly will select one of or some between stimuli that are addressed to them that will be responded. In other words, the coming stimuli are not directly responded without meaning processes or prior thinking. In relation to that, based on Mead, there are four steps of actions that are related to each other and are dialectic unity. Humans and animals have similar actions as well as their dissimilarities. Those four elements differentiate humans from animals covering the impulse, perceptions, manipulations, and consumption (termination).

In symbolic interactionism perspective, it can be summarized as follows: (1) Society can be understood as a system that has certain meaning and interpretation it occurs because each individual in dividing their intention is related to using symbols, such as language in interpersonal communication activity. The activity is expected to form together understanding that can be a behavior guide towards permanent behavioral patterns. (2) Certain views of behavior showing social realities, both physically and naturally, that are actually formed from the process of meanings arrangement. This happens because each person, personally or as a whole, get involved in symbolic interactions. The interaction towards realities generally occurs conventionally and internalized. (3) Agreement between individuals about ideas they own, both as a whole with others or the trust in them, it is a meaning construction that is formed though the process of symbolic interactionism. The trust owned by someone towards others is very important in social life realities. (4) Personal norms appearing in an action in certain situations, basically, are guided by one's characteristics in relating their understanding to the situations. Behavior is not automatically said as responding every external stimulus, but is a result of subjective construction about oneself and others because of the need of social situation [9].
The key aspect in accomplishing self-awareness is the symbol of all interactions between individual that then involves a symbol exchange. The core message from Mead's postulate in symbolic interactionism is that humans have their own self, they are able to become the subject as well as the object of themselves, so that they are able to do actions in relation to their own needs.

\section{CONCLUSIONS}

From the research, it is concluded that political participation of the society in general election is still low, it is due to low political awareness, insufficient quality of human resources because of inequality of education, the low political education level, unstable economic condition, the high level of working batches due to limited job vacancies, unrecovered condition of social and politics, and mental behavior of the society that is ignorant about development policies and others. In addition, other factors influencing political participation of the society are supports from formal or informal leaders, facilities and infrastructures in political events, political education, have interest in certain political aspects.

\section{ACKNOWLEDGEMENT}

The researcher would like to thank Prof. Dr. Karim Suryadi, M.Si., and Dra. Wilodati, M.Si, who have guided and assisted in the research, as well as to Local General Election Commission (KPUD) Sukabumi, all vital people, and the rural communities in Sukabumi, West Java.

\section{REFERENCES}

[1] Mas'oed, M. (2003). Capital Countries and Democracy. Yogyakarta: Pustaka Pelajar.

[2] Local General Election Commission (KPUD). (2014). Sukabumi, West Java.

[3] Raharjo. (2004). The Journal of Rural and Areas Dynamics: Rural Development, Why Is It Disjoined from Expectation?. Vol. 4, No. 4, pp. 3-11. Gadjah Mada University.

[4] Wastutiningsih, S.P. (2004). The Journal of Rural and Areas Dynamics: Farmers' Empowerment and Rural Independency. Vol. 4, No. 4, pp. 12-18. Gadjah Mada University.

[5] Kusnadi, A.E. (2007). Roles of Regents' Leadership in Shaping Rural Communities Political Behavior. Final Research Paper, Indonesia University of Education.

[6] Creswell, J.W. (1994) Research Design: Approaches to Qualitative, Quantitative, and Mixed Methods (Translated). Yogyakarta: Pustaka Pelajar.

[7] Syam, N.W. (2009). Sociology of Communication. Bandung: Humaniora.

[8] Upe, A. (2010). Stream Traditions in Sociology from Positivistic Philosophy to Post Positivistic. Jakarta: Raja Grafindo Persada.

[9] Ritzer, G. (2012). Sociology Theories from Classical Sociology to the Latest Development of Postmodern. Jakarta: Pustaka Pelajar. 